\title{
Radiological evaluation of septal bone variations in the sphenoid sinus
}

\author{
Sfenoid sinüsteki septum varyasyonlarının radyolojik incelenmesi \\ Rıza Dündar', Erkan Kulduk², Fatih Kemal Soy², Mehmet Aslan², Ahmet Erdem Kılavuz², \\ Engin Umut Sakarya ${ }^{4}$, Haşmet YazıcI ${ }^{5}$, Abdülkadir Eren ${ }^{6}$ \\ ${ }^{1}$ Department of Otorbinolaryngology, Kizultepe Government Hospital, Mardin, Turkey \\ ${ }^{2}$ Department of Otorbinolaryngology, Mardin Government Hospital, Mardin, Turkey \\ ${ }^{3}$ Department of Otorhinolaryngology, Malazgirt Government Hospital, Mus, Turkey \\ ${ }^{4}$ Department of Otorhinolaryngology, Bozkır Government Hospital, Konya, Turkey \\ ${ }^{5}$ Department of Otorbinolaryngology, Balıkesir University, Balıkesir, Turkey \\ ${ }^{6}$ Department of Radiology, Kizlltepe Government Hospital, Mardin, Turkey
}

\begin{abstract}
Objective: To determine septal variations and rates of intrasinusal protrusions of optic nerve and internal carotid artery in sphenoid sinus.

Methods: Retrospective analysis of spiral computed tomography scanning of paranasal sinuses of 218 patients diagnosed as acute/chronic sinusitis was performed. Bilateral sphenoid sinuses were evaluated as if a single sinus, septa of this sinus were evaluated in terms of number and configuration. Besides rates of optic nerve and internal carotid artery protrusions were determined.

Results: A total of 5 types of septal variations were detected. A single complete septum ( $\mathrm{n}=132 ; 60.5 \%)$, a single incomplete septum $(\mathrm{n}=66$; $30.2 \%$ ), double septum (complete + incomplete, $\mathrm{n}=6 ; 2.7 \%$ ), two complete septa ( $\mathrm{n}=9 ; 4.1 \%)$, and sphenoid sinuses without septum $(\mathrm{n}=5 ; 2.2 \%)$ were identified. Sixty-four percent of single septum was located in midline, while other types were found immediately right or left side of the midline. Besides, protrusions of optic nerve and internal carotid artery were detected in $39(17.8 \%)$ and 61 (27.9\%) cases, respectively.

Conclusion: Preoperative evaluation with computed tomography and surgical planning dependent on these findings are very important for endoscopic interventions and these approaches minimize potential major intraoperative complications.
\end{abstract}

Keywords: Endoscopic sinus surgery, sphenoid sinus variations.

\section{Özet}

Amaç: Sfenoid sinüste yer alan septum, optik sinir ve internal karotid arter ile ilgili olarak varyatif durumların belirlenmesi.

Yöntem: Akut/kronik sinüzit tanısıyla paranasal sinüs bilgisayarlı tomografi istenen 218 hasta retrospektif olarak taranmıştır. Bu hastaların tomografileri aksiyel ve koronal kesitlerde incelenerek sfenoid sinüs, kemik septa varyasyonları, sayı ve uzanım şekli yönünden sınıflandırılmıs, ayrıca optik sinir ve internal karotid arter protrüzyon valansları hesaplanmıştır.

Bulgular: Radyolojik inceleme sonucunda 5 tip septa varyasyonu saptanmıştır. Yüz otuz iki adet $(\% 60,5)$ tek komplet septumlu, 66 adet (\%30.2) tek inkomplet septumlu, 6 adet (\%2.7) çift septumlu (komplet+inkomplet), 9 adet (\%4.1) çift septumlu (komplet+komplet) ve 5 adet (\%2.2) septumu olmayan sfenoid sinüs tanımlanmıştır. Tek olan septumların \%64 oranında orta hatta olduğu, diğer tiplerin ise orta hattın hemen sağ veya solundan başladığı izlenmiştir. Ayrıca optik sinir ve internal karotid arter protruzyon oranları $(\mathrm{n}=39) 17.8 \%$ ve ( $\mathrm{n}=61) \% 27.9$ olarak bulunmuştur.

Sonuç: Cerrahi öncesi bilgisayarlı tomografi ile yapılan değerlendirme ve cerrahi planlama, endoskopik girişimler için çok büyük önem taşımakta ve olası majör cerrahi komplikasyonların azaltılmasında rol almaktadır.

Anahtar sözcükler: Endoskopik sinüs cerrahisi, sfenoid sinüs varyasyonlar1.
Correspondence: Erkan Kulduk, MD. Department of Otorhinolaryngology,

Mardin Government Hospital, Mardin, Turkey.

e-mail: erkankulduk@yahoo.com

Received: January 20, 2014; Accepted: March 12, 2014; Published online: May 5, 2014
Online available at:

www.jmedupdates.org doi: $10.2399 / \mathrm{jmu} .2014001002$ QR code: 
Sphenoid sinus is an important structure localized in the body of the sphenoid bone. It is separated from critical surrounding structures like optic nerve and chiasm, cavernous sinus, pituitary gland and internal carotid artery by a thin bony lamella. Generally, sphenoid sinus is asymmetrically divided in several compartments by one or more than one septum. Because of its location and close position to important anatomical structures, diagnosis and treatment of sphenoid sinus pathologies are very challenging. ${ }^{[1]}$

Knowledge of the variations of this area is the key point for safe and harmless endoscopic surgery. ${ }^{[2]}$ To be able to perform high quality and safe endoscopic surgery, preoperative planning with accurate diagnosis and under the guidance of imaging modalities as computed tomography (CT) and magnetic resonance imaging (MRI) is a prerequisite. ${ }^{[3]}$

Many radiological techniques have been used for the visualization of sinuses. Conventional imaging technique has a historical value and nowadays it is replaced by CT and MRI. CT is the gold standard imaging modality in inflammatory paranasal sinus diseases and especially in candidates for endoscopic sinus surgery and postoperative recurrences. It is more sensitive than MRI in demonstrating bone tissue invasions. The most important disadvantage of CT which is also more cost-effective and practical than MRI, is ionizing radiation. ${ }^{[3]}$

Depending on wide spectrum of anatomical variations of the sphenoid sinus, in endoscopic interventions devoid of navigation systems, knowledge about the orientation and the number of the sinuses is a must for safe surgery. ${ }^{[4]}$ In our study we also investigated especially variations of the sphenoid sinus. We aimed to expose sphenoid sinus septations, in order to determine septal variations and rates of intrasinusal protrusions of optic nerve $(\mathrm{ON})$ and internal carotid artery (ICA) which might lead to major complications in cases of exposure to surgical trauma.

\section{Materials and Methods}

Retrospective analysis of spiral tomographic CT (Aquilion 16 CFX; Toshiba Medical System, Tokyo, Japan) scan-

Table 1. Clinical and demographic data of the patients.

\begin{tabular}{|c|c|c|}
\hline \multicolumn{2}{|c|}{ Variables } & Group $(n=208)$ \\
\hline \multicolumn{2}{|c|}{ Age $($ mean $\pm S D)$} & $21.8 \pm 3.45$ \\
\hline Gender & $\begin{array}{l}\text { Female } \\
\text { Male }\end{array}$ & $\begin{array}{l}101(46.3 \%) \\
117(53.6 \%)\end{array}$ \\
\hline \multicolumn{2}{|c|}{ Protrusion of optic nerve } & $39(17.8 \%)$ \\
\hline \multicolumn{2}{|c|}{ Protrusion of internal carotid artery } & $61(27.9 \%)$ \\
\hline
\end{tabular}

ning of paranasal sinuses of 218 patients (117 male and 101 female) who consulted to Mardin Government Hospital with complaints of headache, nasal stuffiness and diagnosed as acute /chronic sinusitis was performed using the following parameters: extended images of all paranasal sinuses at a detector configuration of $16 \times 0.5 \mathrm{~mm}$ within a range of $0.5 \mathrm{~mm}$ and a reconstruction width of $0.35 \mathrm{~mm}$. Secondary coronal and sagittal MPRs (multiplanar reconstructions) were constructed from original axial sections. Use of any contrast agent was not required.

Patients who had previously undergone conventional or endoscopic surgery were excluded from the study. Bilateral sphenoid sinuses were evaluated as if a single sinus, septa of this sinus were evaluated in terms of number and configuration. Besides rates of $\mathrm{ON}$ and ICA protrusions were determined.

\section{Results}

Study population consisted of 101 female and 117 male patients with a mean age of $21.8 \pm 3.45$ (range: 18 to 26 ) years. Demographic data were not statistically significant. Clinical and demographic data of the patients were summarized in Table 1. Paranasal CTs obtained on coronal, an axial plane were analyzed. A total of 5 types of septal variations were detected. A single complete septum (Fig. 1) which courses

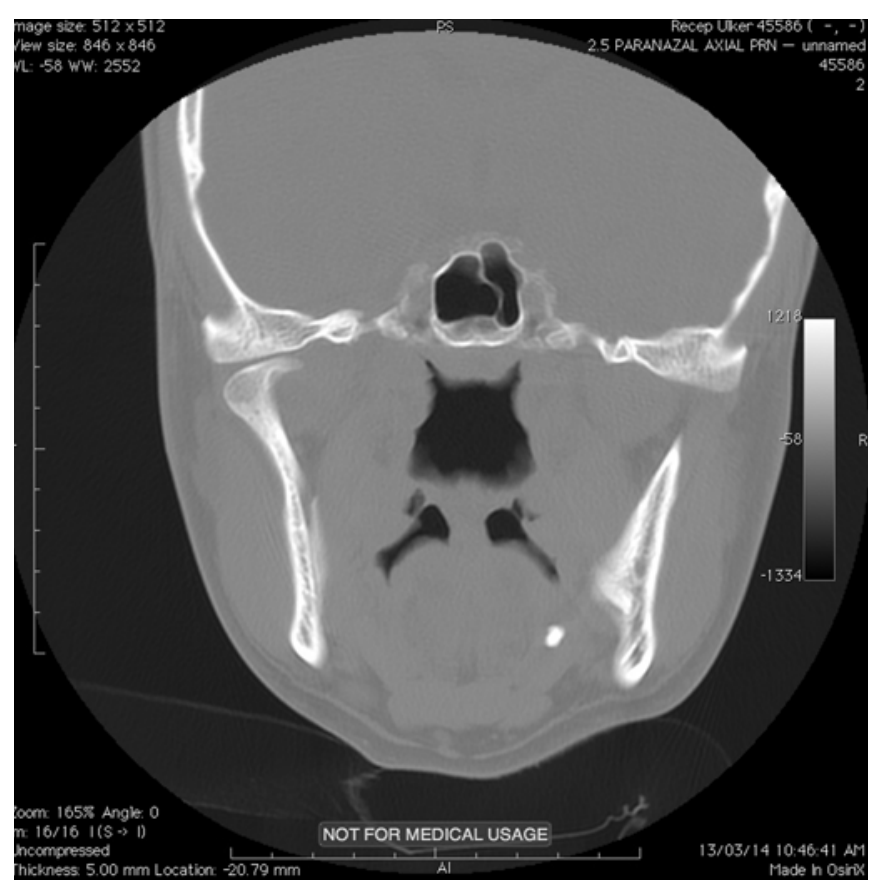

Fig. 1. One single septum coursing and dividing the sphenoid sinus into 2 compartments in an anteroposterior direction. 


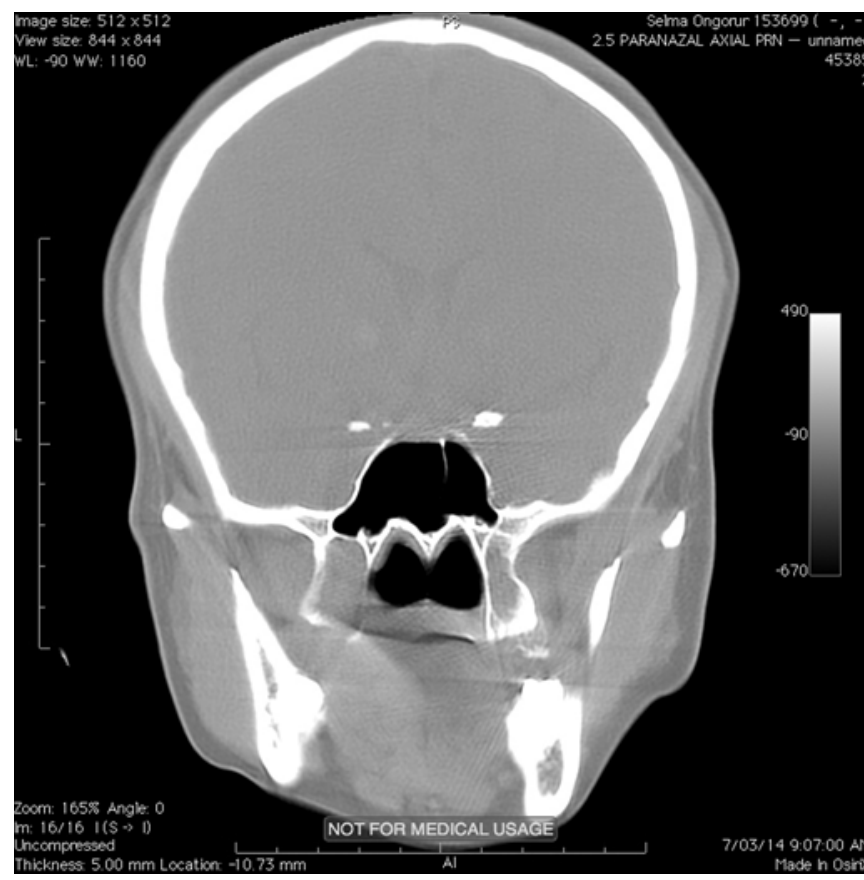

Fig. 2. Sphenoid sinus with a single incomplete septum.

and divides the sphenoid sinus into 2 compartments ( $\mathrm{n}=132$; $60.5 \%)$, a single incomplete septum ( $\mathrm{n}=66 ; 30.2 \%)$ (Fig. 2), double septum (complete + incomplete, $n=6 ; 2.7 \%$ ) (Fig. 3),

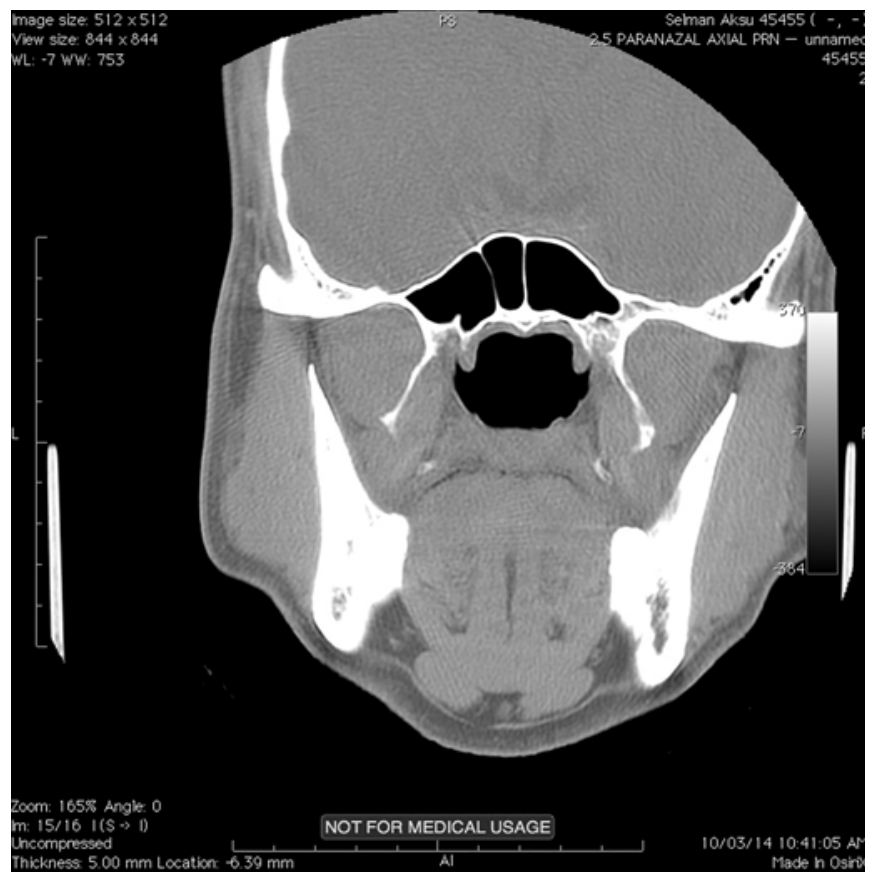

Fig. 4. Sphenoid sinus with a dual septum.

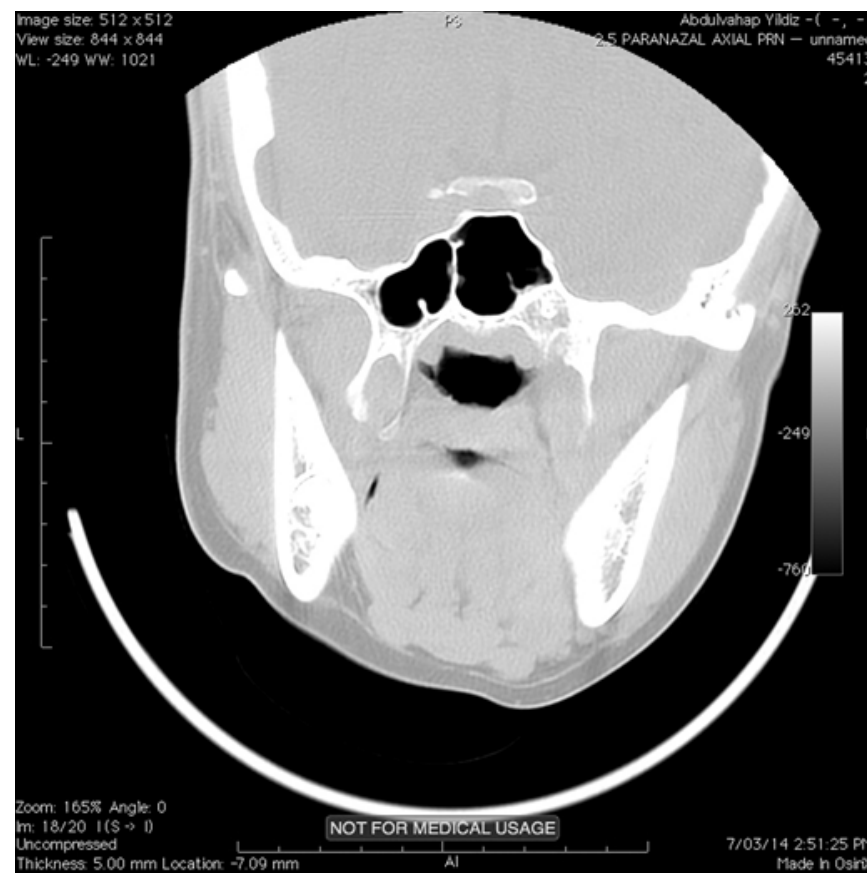

Fig. 3. Sphenoid sinus with complete + incomplete septa.

two complete septa (n=9; 4.1\%) (Fig. 4) and sphenoid sinuses without septum $(\mathrm{n}=5 ; 2.2 \%)$ were identified (Fig. 5). In summary, a single septum, double septum and absence of

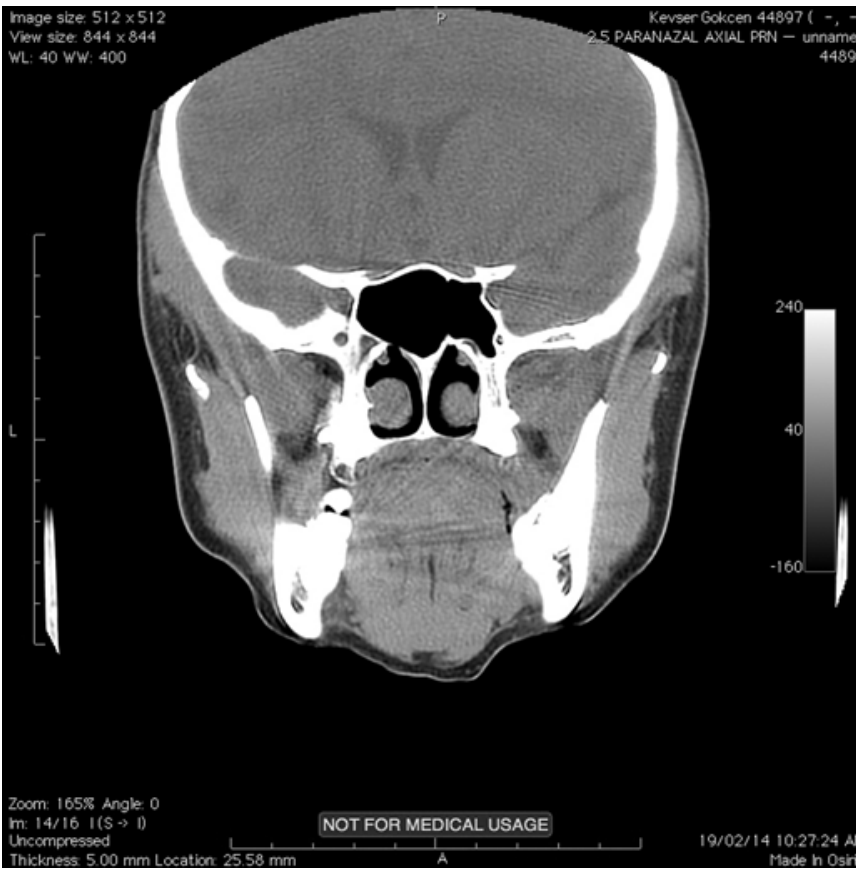

Fig. 5. Sphenoid sinus without septum 
septum were observed in 90.7, 6.8 and $2.2 \%$ of the patients, respectively. Sixty-four percent of single septum was located in midline, while other types were found immediately right or left side of the midline. Besides, protrusions of optic nerve and internal carotid artery were detected in $39(17.8 \%)$ and $61(27.9 \%)$ cases, respectively (Table 1$)$.

\section{Discussion}

Sphenoid sinus is an important structure localized in the body of the sphenoid bone. It is separated from critical surrounding structures like optic nerve and chiasm, cavernous sinus, pituitary gland and internal carotid artery by a thin bony lamella.

Sphenoid sinuses begin to develop from posterior ethmoidal cells at the age of 1 or 2. At 3-4 years of age, sphenoid sinuses extend towards sphenoid bone and grow into greater wings of sphenoid bone and pterygoid laminas. ${ }^{[5]}$ High resolution CT scan may show pneumatization of the sphenoid sinuses as early as 2 years of age. Pneumatization progresses in an inferior and posterolateral direction. The pneumatized basi-sphenoid plate often extends to, but not past, the spheno-occipital synchondrosis in the mature sphenoid sinus. The sinus attains its mature size by the age of 14 years. ${ }^{[5]}$

Functional endoscopic sinus surgery (ESS) has a wide area of application in the treatment of benign, malignant and inflammatory diseases of paranasal sinuses. Recently, endoscopic surgery has been started to be used for the structures located behind the borders of paranasal sinuses. ${ }^{[6]}$ In cases of epistaxis, challenging operations as internal maxillary artery ligation, repairs of cerebrospinal fluid leakage, orbital decompression and pituitary gland interventions can be performed endoscopically. As has been observed, transnasal interventions decrease morbidity and mortality rates when compared with transcranial procedures. ${ }^{[7]}$

Knowledge about anatomical variations of sphenoid sinus and also its relationship with surrounding structures as internal carotid artery, optic nerve, pituitary gland will shorten sphenoid sinus surgery and also prevent morbid or mortal complications. Determination of anatomical variations of this region will be the keypoint in the understanding of the steps of tumoral invasion or spread of inflammatory process. Besides it will guide the management of the relevant pathologies. ${ }^{[8]}$

Many radiological techniques have been used for the visualization of sinuses. Conventional imaging technique has a historical value and nowadays it is replaced by CT and MRI. CT is the gold standard imaging modality in inflammatory paranasal sinus diseases and especially in candidates for endoscopic sinus surgery and postoperative recurrences. It is more sensitive than MRI in demonstrating bone tissue invasions. The most important disadvantage of CT which is also more cost-effective and practical than MRI, is ionizing radiation. ${ }^{[3]}$

This region demonstrates numerous variations which makes major vascular and glandular structures more vulnerable to traumatic injuries. For instance, hyperpneumatization of sphenoid sinus and posterior ethmoid sinuses predisposes to optic nerve injuries. ${ }^{[9]}$ Intraluminal protrusion of internal carotid artery can even cause fatal complications. ${ }^{[10]}$

Generally an asymmetrical septum which separates the sinus into two compartments is observed inside the sphenoid sinus. In various literature studies, the incidence of a single septum has been reported as 33-95 percent. ${ }^{[1]}$ With a few specific exemplary cases the incidence of a single septum was reported as $77 \%$ (Szolar et al. $)^{[12]}$ and $71 \%$ (Hamid et al.), ${ }^{[13]}$ while we found single septum (single complete+single incomplete) in $90.7 \%$ of our cases. These studies indicated that septa were mostly in the paramedian location and more frequently deviated to the right side. In our study, $64 \%$ of single septum was in the midline and other types were localized immediately right or left side of the midline. In similar studies, Banna and Olutula, ${ }^{[14]}$ and Hamid et al. ${ }^{[13]}$ detected absence of sphenoid sinus septation in 11.4 and $10.8 \%$ of their cases, respectively. In our study, we observed lower rate $(2.2 \%)$ relative to those reported in the literature. Finally, Saren et al. ${ }^{[15]}$ detected higher incidence rates (up to $80 \%$ ) for multiple septations, while Hamid et al ${ }^{[13]}$ reported a much lower percentage $(8.7 \%)$. In our study, multiple septations were detected in only $7.1 \%$ of the patients.

As is understood from abovementioned data, sphenoid sinus has miscellaneous anatomical variations. Depending on these variations, in endoscopic interventions performed without the aid of a navigation system, orientation and number of the sinusal septations should be known beforehand for a safe surgery. ${ }^{[4]}$ Since septum does not always have the same configuration in the midline, septum should not be accepted as a reliable surgical landmark.

Because of all these reasons, preoperative evaluation with CT and surgical planning dependent on CT findings are very important for endoscopic interventions and these approaches minimize potential major intraoperative complications.

In patients who will undergo endoscopic sinus surgery, disclosure of anomalies and variations of paranasal sinuses is 
very important, which is also a critical step in the prevention of complications that might emerge during operation.

Conflict of Interest: No conflicts declared.

\section{References}

1. Rowe-Jones J, Mackay I, Colquhoun IC. Cross CT protocol for endoscopic sinus surgery. J Laryngol Otol 1995;109:1057-60.

2. Jones NS. CT of the paranasal sinuses: a review of the correlation with clinical, surgical and histopathological findings. Clin Otolaryngol 2002;27:11-7.

3. Mafee MF. Modern imaging of paranasal sinuses and the role of limited sinus computerized tomography: considerations of time, cost and radiation. Ear Nose Throat J 1994;73:532-45.

4. Elwany S, Elsaend I, Thabet H. Endoscopic anatomy of the sphenoid sinus. J laryngol Otol 1999;113:122-6.

5. Kronomer KA, Mcalister WH. Sinusitis and its imaging in the pediatric population. Pediatr Radiol 1997;27:837-46.

6. Driben JS, Bolger WE, Robles HA. The reability of computerized tomographic detection of the Onodi (sphenoetmoid) cell. Am J Rhinol 1998;12:105-11.

7. Dursun E, Korkmaz H, Safak MA, et al. Paranazal sinüs infeksiyonlarında ostiomeatal kompleksteki anatomik varyasyonlar. KBB ve BBC Dergisi 1998;6:147-56.
8. Erkan Ö, Külekçi M, Bayrak C. Rinosinüzitli hastalarda fonksiyonel endoskopik sinüs cerrahisinin boyutlarının BT ile belirleme-varyasyon ve patolojilerin sıklığı KBB Ihtis Derg 1994;5:408-11.

9. Parsons DS. Chronic sinusitis. A medical or surgical disease? Otolaryngol Clin North Am 1996;29:1-9.

10. Tarhan S, Yücetürk AV, Ünlü HH, Yorulmaz İ, Biçer TY. Enflamatuar paranazal sinüs patolojilerinin değerlendirilmesinde Waters grafisi ve sinırlı sinüs bilgisayarlı tomografisinin tanı değeri. KBB Ihtis Derg 1998;5:112-6.

11. Scuderi AJ,Harnsberger HR, Boyer RS. Pneumatization of the paranasal sinuses; normal features of importance to the accurate interpretation of CT scans and MR images. AJR Am J Roentgenol 1993;160:1101-4.

12. Szolar D,Preidler K, Ranner G, et al. The sphenoid sinus during childhood: Establishment of normal developmental standards by MRI. Surg Radiol Anat 1994;16:193-8.

13. Hamid O, El Fiky L, Hassan O, et al. Anatomic variation of the sphenoid sinus and their impact on trans-sphenoid pituitary surgery. Skull Base 2008;18:9-16

14. Banna M, Olutola PS. Patterns of pneumatization and septation of the sphenoidal sinus. J Can Assoc Radiol 1983;34:291-3.

15. Sareen D. Agarwal AK. Kaul JM. Sethi A. Study of sphenoid sinus anatomy in relation toendoscopic surgery. Int J Morphol 2005;23:261-6.

This is an open access article distributed under the terms of the Creative Commons Attribution-NonCommercial-NoDerivs 3.0 Unported (CC BYNC-ND3.0) Licence (http://creativecommons.org/licenses/by-nc-nd/3.0/) which permits unrestricted noncommercial use, distribution, and reproduction in any medium, provided the original work is properly cited.

Please cite this article as: Dündar R, Kulduk E, Soy FK, Aslan M, Kılavuz AE, Sakarya EU, Yazıcı H, Eren A. Radiological evaluation of septal bone variations in the sphenoid sinus. J Med Updates 2014;4(1):6-10. 